\section{Influencing Stock Production of Mojave Sage and Cape Daisy with the Application of Plant Growth Regulators}

\author{
Sean J. Markovic ${ }^{1}$ and James E. Klett ${ }^{1}$
}

AdDITIONAL INDEX WORDs. Osteospermum, propagation, Salvia pachyphylla, stock plant management, vegetative cuttings

SUMMARY. This study aimed to assess the effects of plant growth regulators (PGRs) on stock plant production of mojave sage (Salvia pachyphylla) and 'Avalanche' cape daisy (Osteospermum hybrid) that received foliar sprays of the following three PGRs: 200 and $400 \mathrm{ppm}$ ethephon; 250 and $500 \mathrm{ppm}$ benzyladenine; and 50 and $100 \mathrm{ppm}$ gibberellic acid 4 and $7\left(\mathrm{GA}_{4+7}\right)$ plus benzyladenine. Vegetative growth [height and width growth index (GI)], the number of vegetative cuttings, and fresh weight (FW) and dry weight (DW) of the harvested vegetative cuttings data were collected. A propagation study was conducted concurrently to determine the effects of the PGR treatments on rooting vegetative cuttings. $\mathrm{GA}_{4+7}$ plus benzyladenine ( 50 and $100 \mathrm{ppm}$ ) increased the production of both mojave sage and 'Avalanche' cape daisy cuttings by $\geq 18 \%$ more than the other treatments. The GI, FW, and DW results showed similar trends across experiments 1 and 2 for each perennial. In the propagation study, the rooting percentage did not differ after 4 weeks, indicating that the use of $\mathrm{GA}_{4+7}$ plus benzyladenine in production protocols could benefit producers of both perennials.

$\mathrm{P}$ roducers work year-round taking cuttings from herbaceous perennials. This task is difficult because perennials flower at different times of the year. Reproductive tissue on cuttings can inhibit root and vegetative development (Gibson and Cerveny, 2005); therefore, it is highly desirable to keep stock plants in a vegetative developmental state. Herbaceous perennial crops need to produce enough vegetative material to justify the cost of the space they occupy on the greenhouse bench. Furthermore, target uniformity is desired. Perennial producers often prune their plants manually to increase vegetative growth. However, manually pruning perennials to encourage vegetative growth can be

Received for publication 17 Sept. 2020. Accepted for publication 11 Feb. 2021.

Published online 17 March 2021

${ }^{1}$ Department of Horticulture and Landscape Architecture, Colorado State University, 301 University Avenue, Fort Collins, CO 80523-1173

Mention of a trademark, proprietary product, or vendor does not constitute a guarantee or warranty of the product by Colorado State University and does not imply its approval to the exclusion of other products or vendors that also may be suitable.

J.E.K. is the corresponding author. E-mail: jim.klett@ colostate.edu.

This is an open access article distributed under the CC BY-NC-ND license (https://creativecommons.org/ licenses/by-nc-nd/4.0/).

https://doi.org/10.21273/HORTTECH04736-20 labor-intensive (Banko and Stefani, 1996) and can add unwarranted expense (Holland et al., 2007). Producers have sought a more convenient approach to increase vegetative growth. However, PGRs have been less commonly used to enhance vegetative plant growth and remove reproductive tissue (Preece and Read, 1993). However, PGR applications are generally less labor-intensive than manual pruning, although phytotoxicity may be a problem for certain crops (Meijón et al., 2009). Three specific PGRs have been identified for their potential benefits for stock plant production: gibberellic acid, benzyladenine, and ethephon.

The $\mathrm{GA}_{4+7}$ treatment uniformly promotes growth primarily through cell elongation throughout plant tissue (Moore, 1984). Therefore, application of $\mathrm{GA}_{4+7}$ to promote plant growth could result in more propagation material from stock plants.
Cytokinins, specifically benzyladenine, have been found to be involved in nearly all aspects of plant growth and development (Leopold and Kriedemann, 1975). Benzyladenine promotes cell enlargement, but not cell elongation as with auxins and gibberellins; therefore, it promotes cell growth in all directions (Preece and Read, 1993). This results in decreased apical dominance if cytokinin levels in the plant are increased (Hartmann et al., 2002). Increasing lateral growth could result in more propagation material from stock plants. Ethephon is an ethylene inducer that enters the plant and breaks down into three molecules: phosphate, chloride, and ethylene. Ethylene has many processes within the plant cell when released into plant systems that affect plant growth and reproductive development (Preece and Read, 1993). Ethephon is widely used to promote auxiliary shoot development without damage to the apical meristem (Hayashi et al., 2001). Increased branching and decreased flower development could result in more vegetative growth for herbaceous perennial stock plants.

Herbaceous perennial responses to PGRs vary across cultural and environmental conditions (Cochran and Fulcher, 2013). Applications of benzyladenine increased branching on 'Ruby Star' coneflower (Echinacea hybrid) at rates as low as $300 \mathrm{ppm}$ (Latimer et al., 2011), but 'Silver Lode' coral bells (Heuchera hybrid) responded minimally to an application of $600 \mathrm{ppm}$ (Latimer and Freeborn, 2015). 'Snow Angel' coral bells and Orange Carpet ${ }^{\mathrm{TM}}$ hummingbird trumpet (Epilobium canum ssp. garrettii 'PWWG01S') had similar results when treated with $\mathrm{GA}_{4+7}$, but the quality of cuttings had disparities (high quality and low quality, respectively) (Markovic and Klett, 2020). The wide range of possible plant responses indicates

\begin{tabular}{llll}
\hline $\begin{array}{l}\text { Units } \\
\text { To convert U.S. to SI, } \\
\text { multiply by }\end{array}$ & U.S. unit & SI unit & $\begin{array}{l}\text { To convert SI to U.S., } \\
\text { multiply by }\end{array}$ \\
\hline 3.7854 & gal & $\mathrm{L}$ & 0.2642 \\
2.54 & inch $(\mathrm{es})$ & $\mathrm{cm}$ & 0.3937 \\
28.3495 & $\mathrm{OZ}$ & $\mathrm{g}$ & 0.0353 \\
1 & $\mathrm{ppm}$ & $\mathrm{mg} \cdot \mathrm{L}^{-1}$ & 1 \\
$\left({ }^{\circ} \mathrm{F}-32\right) \div 1.8$ & ${ }^{\circ} \mathrm{F}$ & ${ }^{\circ} \mathrm{C}$ & $\left({ }^{\circ} \mathrm{C} \times 1.8\right)+32$
\end{tabular}


the importance of continuing the study of herbaceous perennial responses to PGRs.

Mojave sage (Salvia pachyphylla) and 'Avalanche' cape daisy (Osteospermum hybrid) are herbaceous perennials that were used during these experiments. Meetings with greenhouse and nursery operators propagating the two herbaceous perennials resulted in two main production problems with both perennials. These problems were a lack of quality vegetative propagation material from stock plants and low rooting percentage rates during propagation. Based on previous research, it was decided that using PGRs could help resolve these problems.

The main objective of this study was to evaluate vegetative and floral development of mojave sage and 'Avalanche' cape daisy after applications of three commercial PGRs with the active ingredients of gibberellic acid, benzyladenine, or ethephon. This study hypothesized that applications of PGRs would result in increased vegetative propagation material with quantity and quality similar to those of mojave sage and 'Avalanche' cape daisy stock plants and not affect rooting success.

\section{Materials and methods}

STOCK PLANT STUdy. Two experiments involving each perennial were conducted; however, they were not conducted simultaneously. For mojave sage, Expt. I was conducted during Summer and Fall 2017 and repeated in Fall and Winter 2017-18. For 'Avalanche' cape daisy, Expt. 1 was conducted during Fall and Winter 2017-18 and repeated in Spring 2018.

All experiments were conducted at the Colorado State University Horticulture Center, Fort Collins, CO (lat. $40.577953^{\circ} \mathrm{N}$, long. $105.080925^{\circ} \mathrm{W}$; U.S. Department of Agriculture hardiness zone $5 \mathrm{~b}$ ). Plants of uniform size (72-plug tray) were purchased from a local greenhouse (Gulley Greenhouse, Fort Collins, CO). Eighty-four plants of each perennial type were potted in black \#1 ( $0.75 \mathrm{gal})$ containers on 11 July 2017 and 15 July 2018 for mojave sage and on 15 July 2018 and 11 Feb. 2019 for 'Avalanche' cape daisy. The substrate used for mojave sage was a bark mix of intermediate particle size that included coarse peatmoss, perlite, dolomitic and calcitic lime, and a nonionic wetting agent (BM-7; Berger, Saint-Modeste, QC, Canada). 'Avalanche' cape daisy was grown in a peat substrate composed of blonde peatmoss, dolomitic limestone, and a wetting agent (Pindstrup, Ryomgaard, Denmark). Then, four replicates that consisted of three subsamples each (12 total plants) were placed in a completely randomized design and spaced 12 inches apart on the greenhouse bench for each treatment.

During establishment, plants were watered by hand with $14 \mathrm{~N}-$ 1.7P-11.6K water-soluble fertilizer (GreenCare; Blackmore Co., Belleville, MI) at a rate of 200 ppm nitrogen $(\mathrm{N})$. Fertilizer was continuously injected using an inline, water-powered, nonelectric chemical injector (model Dl4MZ2; Dosatron, Clearwater, FL). Drip irrigation was installed after 5 weeks, when the majority of the plants' roots began to strike the sides of the containers. Then, the fertilizer regimen was switched to a continual feed of 20N-4.4P-16.6K water-soluble fertilizer (Grow More, Gardena, CA) at a rate of $200 \mathrm{ppm} \mathrm{N}$. Using $0.5-\mathrm{gal} / \mathrm{h}$ emitters (Rain Bird Corp., Azusa, CA), drip irrigation was applied every other day for $30 \mathrm{~min}$, resulting in an average of $0.75 \mathrm{gal}$ of water per week per plant.

Daytime temperatures were maintained between 65 and $73{ }^{\circ} \mathrm{F}$; night temperatures were kept between 61 and $73{ }^{\circ} \mathrm{F}$. Supplemental lighting was provided for mojave sage stock plant experiments. Light-emitting diode (LED) fixtures (Green Power LED Toplighting Module DR/W MB 200-400V; Philips, Amsterdam, the Netherlands) provided $\approx 90 \%$ red and $10 \%$ blue light from sunrise to sunset daily throughout the greenhouse. Light measurements were obtained using a light sensor (LI-190; LI-COR, Lincoln, $\mathrm{NE})$ to ensure there was no red light bleeding across the greenhouse to disrupt the cape daisy experiments. No supplemental lighting was provided to 'Avalanche' cape daisy after it was determined that additional lighting could induce earlier flowering of the stock plants (Pearson et al., 1995 ).

The three PGRs in this study were applied at the following rates to both perennials: 200 and 400 ppm ethephon (Nufarm Americas, Alsip, IL); 250 and 500 ppm benzyladenine (Fine Agrochemicals, Worcester, $\mathrm{UK})$; and $50 \mathrm{ppm}$ and $100 \mathrm{ppm}$ $\mathrm{GA}_{4+7}$ plus benzyladenine (Valent USA, Fresno, CA). Treatments for both experiments were applied 2 weeks before each monthly data collection over the course of a 4-month period. During Expt. 1 for mojave sage, treatments were applied on 12 Aug., 12 Sept., 14 Oct., and 12 Nov. 2017. During Expt. 2, treatments were applied on 29 Aug., 29 Sept., 30 Oct., and 30 Nov. 2017. During Expt. I for 'Avalanche' cape daisy, treatments were applied on 29 Aug., 29 Sept., 30 Oct., and 30 Nov. 2017. During Expt. 2, treatments were applied on 26 Feb., 26 Mar., 30 Apr., and 31 May 2018. Treatments were applied to foliar runoff, including those in the control group, that were sprayed with plain water using a l-gal hand pump sprayer.

Initial measurements of height and width for each plant were obtained 5 weeks before the first application of PGR treatments. Plant height was measured from the base of the plant to the highest leaf. Plant width was measured twice, with the second measurement perpendicular to the first. These three values were added together and divided by three to determine the GI for each plant. Subsequently, plant height, plant width, the number of cuttings, total FW of cuttings, and total DW of cuttings were measured monthly.

When harvested, two-thirds of the total vegetative growth of each stock plant was left intact to ensure continual plant growth, as suggested by commercial growers. Cuttings were harvested monthly, $\approx 2$ weeks after the PGR applications; ideal cuttings are indicated in Fig. 1. The ideal mojave sage cutting has up to a 3 -inch height and a stem with a $1 / 8$-inch diameter. The ideal 'Avalanche' cape daisy cutting has up to a 4 -inch height and a stem $1 / 4$ inch on the portion without leaves. Next, cuttings from each stock plant were counted, weighed to determine the $\mathrm{FW}$, and placed in a drying oven at $70{ }^{\circ} \mathrm{C}$ for 48 $\mathrm{h}$ to determine the DW. Harvested stock plants were grown for another 4 weeks before another harvest was taken. One month after the last harvest for each experiment, all shoot 
A

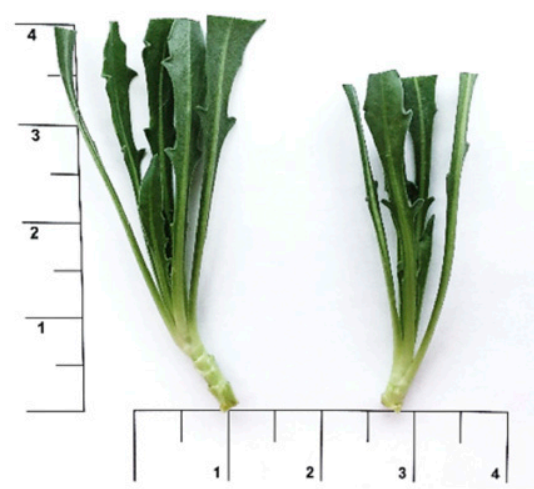

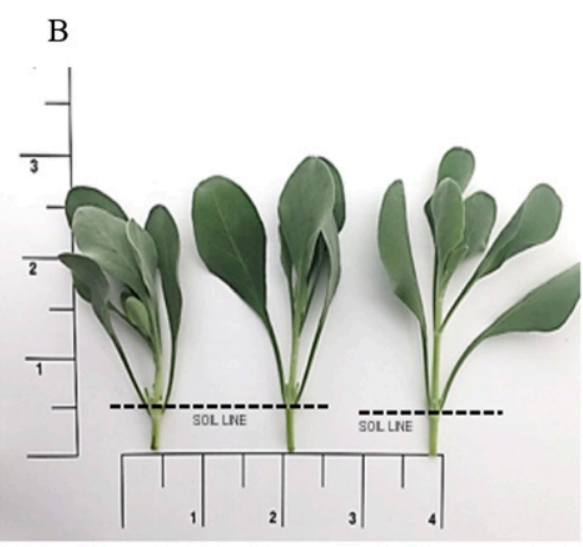

Fig. 1. Visual guide of the 'Avalanche' cape daisy (A) and mojave sage (B) cutting protocol provided by Gulley Greenhouse, Fort Collins, CO. Cuttings show the ideal size and preparation for harvest. Measurements are presented in inches ( 1 inch $=2.54 \mathrm{~cm}$ ).

growth above the soil line was removed, weighed, dried, and weighed on nine of the 12 stock plants from each treatment. This was performed to approximate the average growth of plant tops for each treatment. The other three stock plants were kept for propagation experiments.

Propagation study. Three stock plants for each treatment were randomly selected for each experiment and grown under the same conditions as used during the stock production experiments. The only variable continued to be the different PGRs applied during the stock plant treatments. Three replications for each experiment were conducted with 10 cuttings rooted in a completely randomized design in one propagation flat. Cuttings from mojave sage were collected every 4 weeks: 11 Jan., 8 Feb., and 1 Mar. 2018 for Expt. 1, and 6 Feb., 7 Mar., and 5 Apr. 2019 for Expt. 2. Cuttings from 'Avalanche' cape daisy were harvested every 4 weeks: 6 Feb., 7 Mar., and 5 Apr. 2019 for Expt. 1, and 3 May, 7 June, and 5 July 2019 for Expt. 2. Cuttings were taken during the morning before 11:00 AM, dipped for $5 \mathrm{~s}$ in $500 \mathrm{ppm}$ indole-3-butyric acid/1-naphthylacetic acid (IBA/ NAA) (Dip 'N Gro, Clackamas, OR), and propagated in trays of 72 cells of peatmoss and binding agent (Preforma; Jiffy, Lorain, OH).

A mist timer (NOVA 1626ET; Phytotronics, Earth City, MO) was used to control the amount of moisture applied to cuttings under mist nozzles (03034211-b pcs 25 coolpro c $4 \times 7$ head + ad20; Netafim, Fresno, CA). Bottom heat was provided by heating mats (Redi Heat model RHD 2110; Phytotronics) at a temperature of $75^{\circ} \mathrm{F}$. Cuttings were misted for 10 s throughout each day at varying time intervals each week as follows: week 1 , every $15 \mathrm{~min}$; week 2 , every $30 \mathrm{~min}$; and weeks 3 and 4 , every $60 \mathrm{~min}$. Rooting data were collected at 4 weeks. Data collected included the rooting success percentage during weeks 2 to 4 on the mist bench. The number of visible roots was determined by counting up to 50 individual roots in each cell.

ExPERIMENTAL ANALYSIs. A completely randomized design was used during these experiments. Data analysis was performed using statistical computing software $(\mathrm{R}$ version 3.3.1; R Foundation for Statistical Computing, Vienna, Austria) with car, LSMeans, and ggplot packages; a one-way analysis of variance (ANOVA) was performed separately for the response variables. The stock plant study had response variables with a combined sample size of 48 . Data analyzed included the average number of cuttings per plant, average FW per cutting, average DW per cutting, and final average DW of the total shoot growth from each stock plant replicate. Data were analyzed and averaged over four collections taken for both perennials and were specific for Expts. 1 and 2. Predictor variables matching PGR treatments were included in the statistical models. Pairwise comparisons and least squares means were calculated using the LSmeans package for each response variable. Tukey's adjusted pairwise comparisons were considered and significant differences were noted using $\alpha=0.05$.

The propagation study had response variables and a combined sample size of 30 for each experiment. During these experiments, a randomized design for treatment placement within the propagation tray was used. The successful rooting percentage and average number of visible roots per replicant data were analyzed using an initial arcsine transformation for the rooting percentages. Then, a oneway ANOVA was performed for the rooting percentage and average number of visible roots for each experiment. Predictor variables matching PGR treatments were included in the statistical models. Pairwise comparisons and least squares means were calculated using the LSmeans package for each response variable. Tukey's adjusted pairwise comparisons were considered and significant differences were noted using $\alpha=0.05$.

\section{Results and discussion}

NUMBER OF CUTTINGS HARVESTED. Data for these experiments were averaged across all four harvest dates. There were no differences among the four harvest dates (data not shown). For mojave sage, foliar sprays containing $\mathrm{GA}_{4+7}$ plus benzyladenine (50 and $100 \mathrm{ppm}$ ) resulted in a greater number of cuttings harvested compared with all other treatments used during Expts. 1 and 2 (Fig. 2). For example, compared with the control group, plants treated with $\mathrm{GA}_{4+7}$ plus benzyladenine $(50 \mathrm{ppm})$ produced 8.21 (83.3\%) more cuttings during Expt. 1. Compared with the control, plants treated with $\mathrm{GA}_{4+7}$ plus benzyladenine $(100 \mathrm{ppm})$ produced 11.79 (69.5\%) more cuttings during Expt. 2 (Fig. 2). During Expt. 2, the ethephon $(400 \mathrm{ppm})$ treatment had significantly fewer cuttings, whereas $\mathrm{GA}_{4+7}$ plus benzyladenine (50 and $100 \mathrm{ppm}$ ) treatments had significantly more cuttings than all other treatments.

The number of cuttings also increased with $\mathrm{GA}_{4+7}$ plus benzyladenine (50 and $100 \mathrm{ppm}$ ) during both experiments for 'Avalanche' cape daisy (Fig. 3). During Expt. 1, 


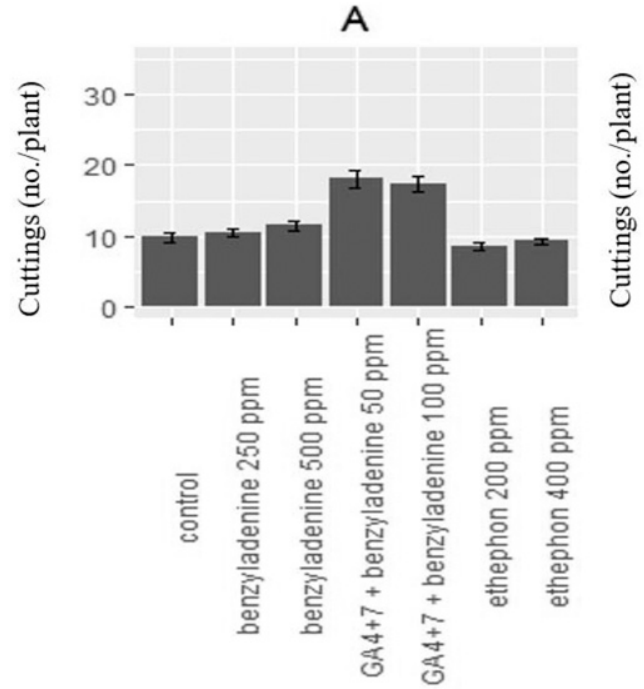

Treatment

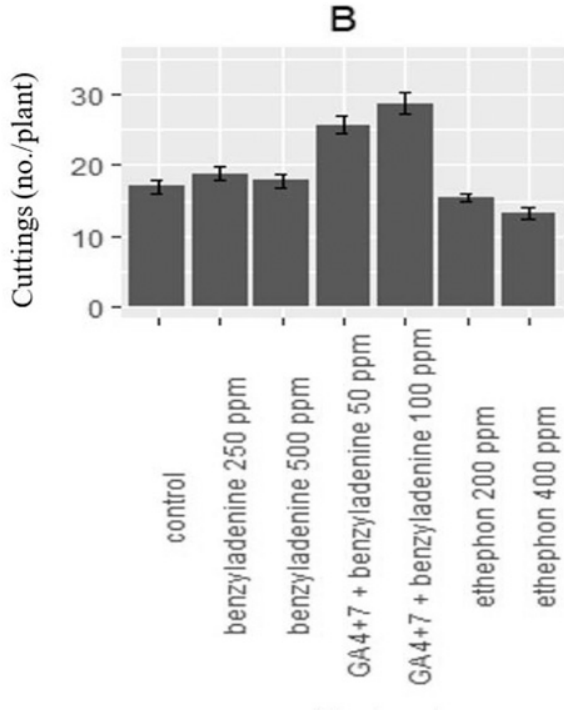

Treatment

Fig. 2. Mean number of cuttings harvested per plant from mojave sage stock plants averaged over four harvest dates for Expt. 1 (A) and Expt. 2 (B) as influenced by six foliar-applied plant growth regulator treatments: benzyladenine at two rates $(\mathbf{2 5 0}$ and $500 \mathrm{ppm})$; gibberellic acid 4 and $7\left(\mathrm{GA}_{4+7}\right)$ plus benzyladenine at two rates $(50$ and $100 \mathrm{ppm})$; and ethephon at two rates (200 and $400 \mathrm{ppm})$. Only water was applied to the control. Error bars represent the SE. Experiments were performed at the Colorado State University Horticulture Center greenhouse, Fort Collins, CO (1 $\left.\mathrm{ppm}=1 \mathrm{mg} \cdot \mathrm{L}^{-1}\right)$.

A

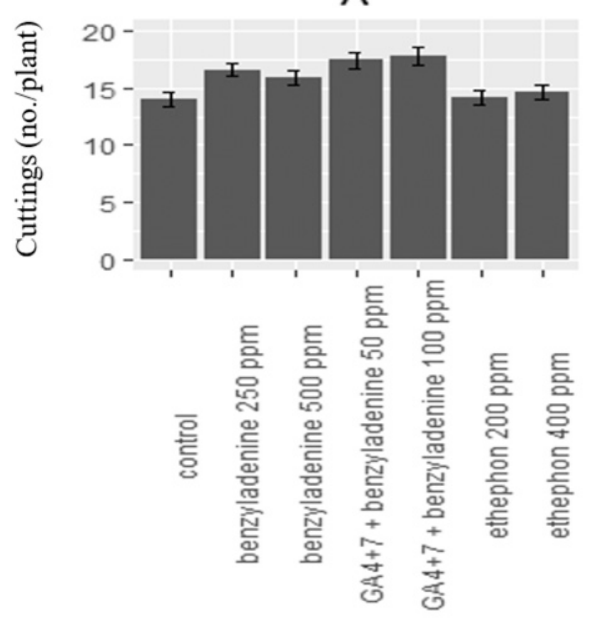

Treatment

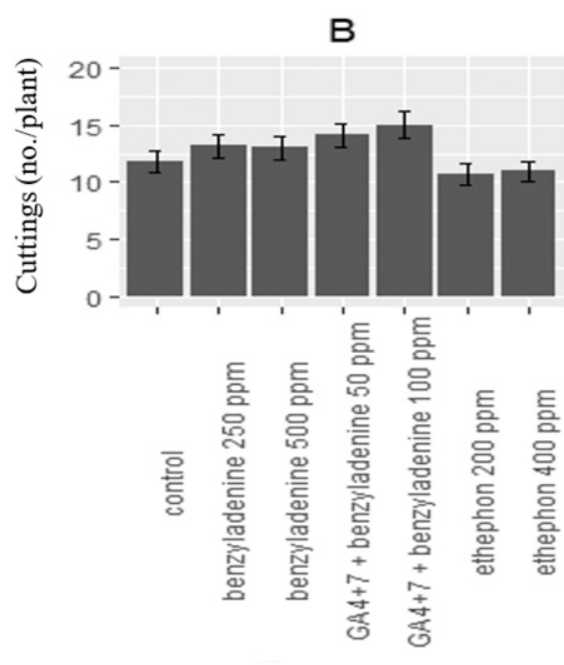

Treatment

Fig. 3. Mean number of cuttings harvested per plant from 'Avalanche' cape daisy stock plants averaged over four harvest dates for Expt. 1 (A) and Expt. 2 (B) as influenced by six foliar-applied plant growth regulator treatments: benzyladenine at two rates (250 and $500 \mathrm{ppm})$; gibberellic acid 4 and $7\left(\mathrm{GA}_{4+7}\right)$ plus benzyladenine at two rates $(50$ and $100 \mathrm{ppm})$; and ethephon at two rates $(200$ and $400 \mathrm{ppm}$ ). Only water was applied to the control. Error bars represent the SE. Experiments were performed at the Colorado State University Horticulture Center greenhouse, Fort Collins, CO $\left(1 \mathrm{ppm}=1 \mathrm{mg} \cdot \mathrm{L}^{-1}\right)$.

$\mathrm{GA}_{4+7}$ plus benzyladenine (100 ppm)-treated stock plants produced an average of $3.86(27.7 \%)$ more cuttings. The control and ethephon (200 and $400 \mathrm{ppm}$ ) treatments had significantly fewer cuttings, whereas $\mathrm{GA}_{4+7}$ plus benzyladenine (50 and $100 \mathrm{ppm}$ ) had significantly more cuttings than other treatments. During Expt. 2, $\mathrm{GA}_{4+7}$ plus benzyladenine
(100 ppm)-treated stock plants produced an average of $3.24(27.5 \%)$ more cuttings (Fig. 3). The ethephon $(200 \mathrm{ppm})$ treatment had significantly fewer cuttings, whereas $\mathrm{GA}_{4+7}$ plus benzyladenine (100 ppm) had significantly more cuttings than all other treatments.

Additional lateral growth due to benzyladenine and elongation growth due to $\mathrm{GA}_{4+7}$ produced more available cuttings. These results were similar to those found for 'Snow Angel' coral bells (Markovic and Klett, 2020). Furthermore, 'Bressingham Bronze' coral bells treated with benzyladenine (1000 ppm) resulted in an effective release of lateral shoots (Martin and Singletary, 1999).

Benzyladenine (250 and 500 $\mathrm{ppm}$ ) resulted in a small increase in the number of cuttings harvested compared with the control that can be attributed to increased lateral branching on the stock plants (Figs. 2 and 3). Another study showed lateral or basal branches and/or leaders treated with benzyladenine (300 and $600 \mathrm{ppm})$; these treatments resulted in significant increases in some herbaceous perennial liners when treated with benzyladenine (Grossman et al., 2012). Ethephon (200 and $400 \mathrm{ppm}$ ) resulted in growth similar to that of the control, with small increases or decreases in the number of cuttings harvested for both mojave sage and 'Avalanche' cape daisy. The inclusion of ethephon in this study was based on previous research indicating that plants treated with ethephon would maintain vegetative growth and induce abscission of flower buds (Walters and Lopez, 2018). No flowering was observed throughout the experiments with either perennial for any treatment; therefore, ethephon did not have an opportunity to show the preconceived effect of reproductive tissue suppression compared with a control including flowering stock plants.

FRESH AND DRY WEIGHT PER CUTTING. The FW was measured immediately after harvesting cuttings from stock plants and used to determine the quality of harvested cuttings. The FW has been a better indication of cutting quality than DW (Brown and Klett, 2020; Markovic and Klett, 2020). The FW of mojave sage in Expt. I did not differ among treatments (Table 
Table 1. Growth index, fresh weight of individual cuttings, and dry weight of individual cuttings of mojave sage averaged over four harvest dates (Expts. 1 and 2) as influenced by six plant growth regulator treatments.

\begin{tabular}{|c|c|c|c|c|}
\hline Treatment $^{\mathrm{z}}$ & Rate $(\mathrm{ppm})^{\mathrm{y}}$ & Fresh wt $(\mathrm{g})^{\mathrm{x}}$ & Dry wt $(\mathrm{g})$ & Growth index $(\mathrm{cm})^{\mathrm{w}}$ \\
\hline \multicolumn{5}{|l|}{ Expt. 1} \\
\hline Control & 0 & 1.93 & 0.56 & $8.21 \mathrm{bc}^{\mathrm{v}}$ \\
\hline Benzyladenine & 250 & 1.82 & 0.53 & $7.70 \mathrm{ab}$ \\
\hline Benzyladenine & 500 & 1.87 & 0.53 & $8.08 \mathrm{bc}$ \\
\hline $\mathrm{GA}_{4+7}+$ benzyladenine & 50 & 1.81 & 0.45 & $9.53 \mathrm{~d}$ \\
\hline $\mathrm{GA}_{4+7}+$ benzyladenine & 100 & 1.62 & 0.42 & $8.90 \mathrm{~cd}$ \\
\hline Ethephon & 200 & 1.88 & 0.61 & $6.98 \mathrm{a}$ \\
\hline Ethephon & 400 & 1.90 & 0.57 & $7.40 \mathrm{ab}$ \\
\hline$P$ value & & 0.727 & 0.204 & 0.001 \\
\hline \multicolumn{5}{|l|}{ Expt. 2} \\
\hline Control & 0 & $1.69 \mathrm{bc}$ & $0.25 \mathrm{~b}$ & $11.08 \mathrm{~b}$ \\
\hline Benzyladenine & 250 & $1.44 \mathrm{ab}$ & $0.21 \mathrm{ab}$ & $11.15 b c$ \\
\hline Benzyladenine & 500 & $1.65 \mathrm{bc}$ & $0.23 \mathrm{~b}$ & $11.09 \mathrm{~b}$ \\
\hline $\mathrm{GA}_{4+7}+$ benzyladenine & 50 & $1.44 \mathrm{ab}$ & $0.21 \mathrm{ab}$ & $12.15 \mathrm{~cd}$ \\
\hline $\mathrm{GA}_{4+7}+$ benzyladenine & 100 & $1.15 \mathrm{a}$ & $0.17 \mathrm{a}$ & $12.27 \mathrm{~d}$ \\
\hline Ethephon & 200 & $1.73 \mathrm{bc}$ & $0.23 \mathrm{~b}$ & $10.7 \mathrm{l} \mathrm{b}$ \\
\hline Ethephon & 400 & $1.89 \mathrm{c}$ & $0.26 \mathrm{~b}$ & $9.13 \mathrm{a}$ \\
\hline$P$ value & & 0.001 & 0.001 & 0.001 \\
\hline
\end{tabular}

${ }^{\mathrm{z}}$ Treatments were foliar. The control received water only. $\mathrm{GA}_{4+7}=$ gibberellic acid 4 and 7 .

${ }^{\mathrm{y}} \mathrm{l} \mathrm{ppm}=1 \mathrm{mg} \cdot \mathrm{L}^{-1}$.

${ }^{\mathrm{x}}$ Total fresh weights and dry weights were obtained for each plant harvested. The average individual cutting weight was determined using the total weight and dividing by the number of cuttings harvested from the single plant. $1 \mathrm{~g}=0.0353 \mathrm{oz}$.

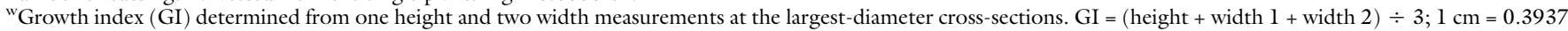
inches.

${ }^{v}$ Mean separation in columns with Tukey's adjusted least squares means at $P \leq 0.05$ (lowercase letters).

1). However, in Expt. 2, $\mathrm{GA}_{4+7}$ plus benzyladenine-treated cuttings had a lower FW than the control and ethephon-treated plants. One possible reason for these findings is the increased overall plant growth between the time of Expt. 1 and that of Expt. 2. The increase in growth could be attributed to better overall plant care during Expt. 2 because of experience gained during the first experiment. The DWs followed the same trends as those of FW during both experiments; no statistical differences were observed during Expt. 1, but differences were observed during Expt. 2 (Table 1). The successful rooting results showed no detrimental effects in $\mathrm{GA}_{4+7}$ plus benzyladenine cuttings, with an average success rate of $77 \%$; the control had an average success rate of $76.5 \%$ (data not shown). Low FW during previous experiments had a negative effect on the rooting success of Orange Carpet $^{\mathrm{TM}}$ hummingbird trumpet (Markovic and Klett, 2020).

The FWs of 'Avalanche' cape daisy during Expts. 1 and 2 were not statistically different among treatments (Table 2). During Expts. 1 and 2 , the DW of control plants was not statistically different from those of the six PGR treatments. Therefore, when FWs and DWs of PGR treatments were statistically similar to those of the control, the quality of the cuttings was similar, as found during previous perennial PGR research (Markovic and Klett, 2020). The propagation experiment results confirmed that FW and DW had few effects on the successful rooting of cuttings.

Growth InDEx. The $\mathrm{GA}_{4+7}$ plus benzyladenine $(50$ and $100 \mathrm{ppm})$ treatment significantly increased the overall growth (Table 1); this was similar to the results observed for coral bells (Ackerman and Hamernik, 1994). Ethephontreated stock plants had the least amount of growth; however, they had some of the larges FWs (Table 1). Ethephon added visually observed growth to the stem thickness of plants, but not to the height and width. These results contradict the results of research involving a broad range of annual floriculture crops that indicated that biomass accumulation was reduced with ethephon applications (Miller et al., 2012). The increased girth of cuttings and successful rooting rates suggest a correlation between FW and increased rooting success for mojave sage.
The GI for 'Avalanche' cape daisy showed trends similar to those of mojave sage. Treatment with $\mathrm{GA}_{4+7}$ plus benzyladenine $(50 \mathrm{ppm})$ resulted in a significant increase in growth when compared with other treatments for Expt. 1 (Table 2). The combination of $\mathrm{GA}_{4+7}$ and benzyladenine increased lateral growth and elongation of lateral branches, which explained the increase in overall growth of treated stock plants. However, these results could not be duplicated during Expt. 2.

Propagation experiments. Mojave sage rooting rates ranged from $70 \%$ with cuttings treated with benzyladenine $(500 \mathrm{ppm})$ to $91.5 \%$ with cuttings treated with ethephon (400 ppm) (data not shown). Although rooting percentages did not significantly differ among treatments, ethephon-treated cuttings had rooting percentages more than $80 \%$. This is the minimum percent that growers look for when propagating perennial crops.

The number of visible roots on cuttings differed between treatments. The $\mathrm{GA}_{4+7}$ plus benzyladenine (50 and $100 \mathrm{ppm}$ ) treatment resulted in successful rooting, but the lower number of visible roots indicated that the speed at which rooting occurred 
Table 2. Growth index, number of cuttings harvested, fresh weight of individual cuttings, and dry weight of individual cuttings of 'Avalanche' cape daisy averaged over four harvest dates (Expts. 1 and 2) as influenced by six foliar-applied plant growth regulator treatments.

\begin{tabular}{|c|c|c|c|c|}
\hline Treatment $^{\mathrm{z}}$ & Rate $(\mathrm{ppm})^{\mathrm{y}}$ & Fresh wt $(g)^{x}$ & Dry wt (g) & Growth index $(\mathrm{cm})^{\mathrm{w}}$ \\
\hline \multicolumn{5}{|l|}{ Expt. 1} \\
\hline Control & 0 & 5.99 & $0.57 \mathrm{~b}$ & $12.04 \mathrm{ab}^{\mathrm{v}}$ \\
\hline Benzyladenine & 500 & 5.34 & $0.48 \mathrm{ab}$ & $11.46 \mathrm{a}$ \\
\hline $\mathrm{GA}_{4+7}+$ benzyladenine & 50 & 5.93 & $0.54 \mathrm{~b}$ & $12.51 \mathrm{~b}$ \\
\hline $\mathrm{GA}_{4+7}+$ benzyladenine & 100 & 5.49 & $0.50 \mathrm{ab}$ & $12.01 \mathrm{ab}$ \\
\hline$P$ value & & 0.129 & 0.005 & 0.006 \\
\hline \multicolumn{5}{|l|}{ Expt. 2} \\
\hline Control & 0 & 6.61 & $0.76 \mathrm{ab}$ & 10.88 \\
\hline Benzyladenine & 250 & 6.81 & $0.81 \mathrm{~b}$ & 11.33 \\
\hline Benzyladenine & 500 & 5.77 & $0.65 \mathrm{ab}$ & 10.95 \\
\hline $\mathrm{GA}_{4+7}+$ benzyladenine & 50 & 6.60 & $0.75 \mathrm{ab}$ & 11.88 \\
\hline$P$ value & & 0.094 & 0.063 & 0.404 \\
\hline
\end{tabular}

${ }^{\mathrm{z}}$ Treatments were foliar. The control received water only. $\mathrm{GA}_{4+7}=$ gibberellic acid 4 and 7 .

${ }^{\mathrm{y}} \mathrm{l} \mathrm{ppm}=1 \mathrm{mg} \cdot \mathrm{L}^{-1}$.

${ }^{\mathrm{x}}$ Total fresh weights and dry weights were obtained for each plant harvested. The average individual cutting weight was determined using the total weight and dividing by the number of cuttings harvested from the single plant. $1 \mathrm{~g}=0.0353 \mathrm{oz}$.

${ }^{w}$ Growth index $($ GI $)$ determined from one height and two width measurements at the largest-diameter cross-sections. GI $=($ height + width $1+$ width 2$) \div 3 ; 1 \mathrm{~cm}=0.3937$ inch.

${ }^{v}$ Mean separation in columns with Tukey's adjusted least squares means at $P \leq 0.05$ (lowercase letters).

Table 3. Influence of six foliar-applied plant growth regulator treatments on mojave sage stock plant: benzyladenine at two rates $(250$ and $500 \mathrm{ppm})$; gibberellic acid 4 and $7\left(\mathrm{GA}_{4+7}\right)+$ benzyladenine at two rates (50 and 100 ppm); and ethephon at two rates $(200$ and $400 \mathrm{ppm})$. Data were collected after 4 weeks under mist and averaged over harvest dates during Expt. 1 (Jan. to Mar. 2018) and Expt. 2 (Feb. 2017 to Apr. 2019). Experiments were performed at the Colorado State University Horticulture Center greenhouse, Fort Collins, CO.

\begin{tabular}{|c|c|c|c|}
\hline \multirow[b]{3}{*}{ Treatment $^{\mathrm{z}}$} & \multirow[b]{3}{*}{ Rate $(\mathrm{ppm})^{\mathrm{y}}$} & Expt. 1 & Expt. 2 \\
\hline & & \multicolumn{2}{|c|}{ Visible roots, $\overline{\text { no./cutting }}$} \\
\hline & & \multicolumn{2}{|c|}{ Mean $(95 \%$ confidence interval $)$} \\
\hline Control & 0 & $11.6(5.4-17.9) \mathrm{ab}^{\mathrm{x}}$ & $20.7(16.3-25.1) b$ \\
\hline Benzyladenine & 250 & $17.2(10.9-23.4) \mathrm{ab}$ & $12.6(8.5-16.8) a b$ \\
\hline Benzyladenine & 500 & $20.8(14.9-26.7) b$ & $17.3(12.0-22.7) \mathrm{ab}$ \\
\hline $\mathrm{GA}_{4+7}+$ benzyladenine & 50 & $5.9(0.0-12.4) \mathrm{a}$ & $7.9(3.6-12.2) \mathrm{a}$ \\
\hline $\mathrm{GA}_{4+7}+$ benzyladenine & 100 & $7.0(0.5-13.5) \mathrm{a}$ & $10.6(6.4-14.8) \mathrm{a}$ \\
\hline Ethephon & 200 & $20.8(14.7-26.9) \mathrm{b}$ & $15.9(11.8-20.0) \mathrm{ab}$ \\
\hline Ethephon & 400 & $14.1(8.3-19.9) \mathrm{ab}$ & $19.9(15.9-23.9) b$ \\
\hline
\end{tabular}

${ }^{\mathrm{z}}$ Treatments were foliar. The control received water only.

${ }^{\mathrm{y}} 1 \mathrm{ppm}=1 \mathrm{mg} \cdot \mathrm{L}^{-1}$.

${ }^{x}$ Mean separation in columns with Tukey's adjusted least squares means at $P \leq 0.05$ (lowercase letters).

might have been affected (Table 3 ). Gibberellic acid 4 has been shown to be less persistent than gibberellic acid 3 (Rademacher, 2015). Gibberellic acid 4 may be better-suited for propagation when long-lasting effects are not desired and may inhibit the successful rooting of cuttings (Rademacher, 2015). Although, GA inhibits adventitious root development and can affect lateral branching
(Preece and Read, 1993), GA 4 could have a reduced effect on rooting compared with gibberellic acid 3 . Data were collected for these experiments during a period of only 4 weeks. Extending this period to 6 to 8 weeks might show whether visible roots increased for $\mathrm{GA}_{4+7}$ plus benzyladenine-treated cuttings. However, producers prefer as short of a timeframe as possible for rooting herbaceous perennials because of the high costs of maintaining greenhouse space.

The effect of different PGRs applied to stock plants had few effects on the successful propagation of ' $\mathrm{Av}$ alanche' cape daisy. The results of Expts. 1 and 2 indicated no differences in the rooting percentage or number of visible roots of cuttings across all treatments. Successful rooting $(100 \%)$ occurred with all treatments in Expts. 1 and 2 (data not shown). The ease of rooting 'Avalanche' cape daisy along with the increase in cutting numbers with applications of $\mathrm{GA}_{4+7}$ plus benzyladenine should benefit commercial producers.

\section{Conclusions}

These studies were conducted to determine whether $\mathrm{GA}_{4+7}$ plus benzyladenine, benzyladenine, and ethephon applications can improve the stock plant production of perennials. The $\mathrm{GA}_{4+7}$ plus benzyladenine treatment appears to have the greatest potential for improving the propagation of mojave sage and 'Avalanche' cape daisy. This can be attributed to an increase in plant growth during the 4-week intervals between harvests 
with $\mathrm{GA}_{4+7}$ and the increased lateral growth resulting from the addition of benzyladenine. The use of $\mathrm{GA}_{4+7}$ plus benzyladenine increased cuttings harvested for both perennials and had no negative effects on the ability of a cutting to produce roots. However, $\mathrm{GA}_{4+7}$ plus benzyladenine applied to mojave sage may result in fewer roots and longer times until full rooting compared with other treatments. Based on these experiment results, we recommend using $\mathrm{GA}_{4+7}$ plus benzyladenine on mojave sage and 'Avalanche' cape daisy stock plants to increase production.

\section{Literature cited}

Ackerman, R. and H. Hamernik. 1994. Gibberellic acid to extend shoots and bud break on Heuchera and Scabiosa. Proc. Intl. Plant. Prop. Soc. 44:545-546.

Banko, T.J. and M.A. Stefani. 1996. Growth response of large, established shrubs to cutless, atrimmec, and trimcut. J. Environ. Hort. 14:177-181, doi: 10.24266/0738-2898-14.4.177.

Brown, S.G. and J.E. Klett. 2020. Impacts of growth substrate and container size on cutting production from 'Snow Angel' coral bells stock plants. Hort Technology 30:185-192, doi: 10.21273/horttech 04495-19.

Cochran, D. and A. Fulcher. 2013. Type and rate of plant growth regulator influence vegetative, floral growth, and quality of Little Lime ${ }^{\mathrm{TM}}$ hydrangea. HortTechnology 23:306-311, doi: 10.21273/horttech.23.3.306.

Gibson, J.L. and C.B. Cerveny. 2005. Stock plant production and management basics for small greenhouse businesses. Univ. Florida Ext. Bul. ENH1021. 15 Oct. 2020. <http://ufdcimages.uflib.ufl. $\mathrm{edu} / \mathrm{IR} / 00 / 00 / 17 / 42 / 00001 /$ EP28400.pdf>.

Grossman, M., J. Freeborn, H. Scoggins, and J.G. Latimer. 2012. Benzyladenine increases branching but reduces root growth of herbaceous perennial liners. HortScience 47:1085-1090, doi: 10.21273/hortsci. 47.8.1085

Hartmann, H.T., D.E. Kester, F.T. Davies, and R.L. Geneve. 2002. Plant propagation: Principles and practices. 7 th ed. Pearson Education, Upper Saddle River, NJ.

Hayashi, T., R.D. Heins, A.C. Cameron, and W.H. Carlson. 2001. Ethephon influences flowering, height, and branching of several herbaceous perennials. Scientia Hort. 91:305-323, doi: 10.1016/s03044238(01)00225-4.

Holland, A.S., G.J. Keever, J.R. Kessler, and F. Dane. 2007. Single cyclanilide applications promote branching of woody ornamentals. J. Environ. Hort. 25:139-144, doi: 10.24266/0738-2898-25.3.139.

Latimer, J.G., J. Freeborn, and V. Groover. 2011. Benzyladenine increases branching of herbaceous perennials. Acta Hort. 886:163-166, doi: 10.17660/ actahortic.2011.886.21.

Latimer, J.G. and J. Freeborn. 2015. Improving quality of containerized herbaceous perennials with a tank mix of Configure and Piccolo. E-GRO Alerts $4(5): 1-5$.

Leopold, A.C. and P.E. Kriedemann. 1975. Plant growth and development. 2nd ed. McGraw-Hill, New York, NY.

Markovic, S.J. and J.E. Klett. 2020. Increasing stock production of two herbaceous peren- nials with the application of plant growth regulators. HortTechnology 30:421-427, doi: 10.21273/horttech04492-19.

Martin, S.A. and S. Singletary. 1999. N6_Benzyladenine increases lateral offshoots in a number of perennial species. Proc. Intl. Plant. Prop. Soc. 49:329334.

Miller, W.B., N.S. Mattson, X. Xie, D. Xu, C.J. Currey, K.L. Clemens, R.G. Lopez, M. Olrich, and E.S. Runkle. 2012. Ethephon substrate drenches inhibit stem extension of floriculture crops. HortScience 47:13121319, doi: 10.21273/hortsci.47.9.1312.

Meijón, M., R. Rodrıquez, M. Canal, and I. Feito. 2009. Improvement of compactness and floral quality in azalea by means of application of plant growth regulators. Scientia Hort. 119:169-175, doi: 10.1016/j.scienta.2008.07.023.

Moore, G.M. 1984. Mechanisms of hormone action in plants. Proc. Intl. Plant. Prop. Soc. 34:79-90.

Pearson, S., A. Parker, P. Hadley, and H.M. Kitchener. 1995. The effect of photoperiod and temperature on reproductive development of cape daisy (Osteospermum jucundum cv. 'Pink Whirls'). Scientia Hort. 62:225-235, doi: 10.1016/0304-4238(95)00792-r.

Preece, J.E. and P.E. Read. 1993. The biology of horticulture: An introductory textbook. Wiley, New York, NY.

Rademacher, W. 2015. Plant growth regulators: Backgrounds and uses in plant production. J. Plant Growth Regul. 34:845-872, doi: 10.1007/s00344-0159541-6.

Walters, K. and R. Lopez. 2018. The efficacy of ethephon foliar sprays is influenced by carrier water alkalinity and ambient air temperature at application. HortScience 53:1835-1841, doi: 10.21273/ hortscil3426-18. 